\title{
PReS-FINAL-2303: Exploring potential differences in demographics, family history and disease characteristics in JSLE patients with different age of onset
}

\author{
N Groot", AM Midgley, L Watson, C Roberts, MW Beresford, UK JSLE Study Group \\ From 20th Pediatric Rheumatology European Society (PReS) Congress \\ Ljubljana, Slovenia. 25-29 September 2013
}

\section{Introduction}

Juvenile-onset SLE (JSLE) is a severe auto-immune disease that can occur in children at any age. Variations regarding the extent of organ involvement, disease activity and damage are found in different age categories. Factors that may contribute to an earlier age of onset are gender, ethnicity and positive family history of SLE. It has been shown that JSLE has a more aggressive disease course compared to adult onset SLE. Correspondingly, it seems that disease severity in younger JSLE patients increases with decreasing age ${ }^{1,2,4}$. However, there is some conflicting evidence.

\section{Objectives}

To determine the differences in gender, ethnicity and family history of SLE in JSLE patients with age of onset $<10$ years and $>10$ years respectively, and to characterize differences in disease characteristics (namely activity, damage, organ involvement) between these groups.

\section{Methods}

Data on patient demographics, family history and disease activity (BILAG) and damage (SLICC) at diagnosis and last follow-up visit were collected from the UK JSLE Cohort Study database. Patients were divided into two age categories based on age of onset ( $\leq 10$ or $>10$ years) and were analyzed. BILAG scores of a subset of patients $(n=24)$ who were followed for five years were analyzed, to evaluate influence of disease duration.

Institute of Child Health, University of Liverpool, Alder Hey Children's NHS Foundation Trust Hospital, Liverpool, UK

\begin{tabular}{lcc}
\hline Age at Diagnosis & $<\mathbf{1 0} \mathbf{y r s ,} \mathbf{n}=\mathbf{9 2}$ & $>\mathbf{1 0} \mathbf{y r s ,} \mathbf{n}=\mathbf{2 2 1}$ \\
\hline Ethnicity: & $15 \%$ & $7 \%$ \\
Black & $27 \%$ & $28 \%$ \\
Asian & $46 \%$ & $53 \%$ \\
Caucasian & & \\
Family history SLE & $16 \%$ & $11 \%$ \\
BILAG at onset (median \pm IQR) & $5.5 \pm 12$ & $8.0 \pm 11$ \\
BILAG at last visit (median \pm IQR) & $2.00 \pm 3$ & $2.00 \pm 3$ \\
\hline
\end{tabular}

duration. Five years after disease onset, disease activity in the $<10$ group $(\mathrm{n}=15)$ was $1 \pm 3$, in the $>10$ group $(\mathrm{n}=9)$ 
it was $4 \pm 5(\mathrm{p}=0.290)$. This indicates that for most patients in this cohort, their disease is probably managed well.

\section{Conclusion}

In contrast to other published cohorts, there were no striking differences in demographics, family history or disease characteristics in this cohort between children diagnosed before or after the age of 10 years old.

\section{Disclosure of interest}

None declared.

Published: 5 December 2013

Cite this article as: Groot et al: PReS-FINAL-2303: Exploring potential

differences in demographics, family history and disease characteristics

in JSLE patients with different age of onset. Pediatric Rheumatology 2013

11(Suppl 2):P293.

Submit your next manuscript to BioMed Central and take full advantage of:

- Convenient online submission

- Thorough peer review

- No space constraints or color figure charges

- Immediate publication on acceptance

- Inclusion in PubMed, CAS, Scopus and Google Scholar

- Research which is freely available for redistribution

Submit your manuscript at www.biomedcentral.com/submit 